\title{
The Mechanical Characteristics and Experimental Study of the Stratospheric Airship
}

\author{
Xu Ning1, Ping Liu ${ }^{1,2 *}$, Zhihong Pan ${ }^{1}$ \\ ${ }^{1}$ Jiangsu University of Science and Technology, Zhenjiang, China \\ ${ }^{2}$ Southeast University, Nanjing, China \\ Email: qzxuning@163.com, liupinghaiyan@163.com, *liupinghaiyan@163.com,zhhpan@163.net
}

How to cite this paper: Ning, X., Liu, P. and Pan, Z.H. (2021) The Mechanical Characteristics and Experimental Study of the Stratospheric Airship. Journal of Applied Mathematics and Physics, 9, 183-196. https://doi.org/10.4236/jamp.2021.91013

Received: December 30, 2020

Accepted: January 26, 2021

Published: January 29, 2021

Copyright $\odot 2021$ by author(s) and Scientific Research Publishing Inc. This work is licensed under the Creative Commons Attribution International License (CC BY 4.0).

http://creativecommons.org/licenses/by/4.0/ (c) (i) Open Access

\begin{abstract}
Stratospheric airship is a special near-space air vehicle which has lots of advantages than other traditional flying aircrafts, such as long endurance, strong survival ability, low cost, excellent resolution detector etc. In addition, the stratospheric airship can be an ideal stratospheric bearing platform. This paper firstly gave an overview describing some technical differences between the stratospheric airship and the traditional airship, including the working environment, design specifications, structure characteristics, energy system, flying modes, and so on. Some technical difficulties including the materials, power system which apply to the stratospheric airship and deformation of the huge hull, super-heating effect, and station-keeping were discussed. Furthermore, technical target, technical specifications, design concept, and overview of flying tested about two stratospheric demonstration airships which were representative achievements of the research on the stratospheric airship in China were introduced. Finally, the predictions about the progress and direction of development were discussed.
\end{abstract}

\section{Keywords}

Stratospheric Airship, Demonstration Test, Membrane Structure

\section{Introduction}

The stratospheric airship is referred as a Lighter-Than-Air aircraft which can float at least a diurnal cycle at about $20-30 \mathrm{~km}$ high altitude [1] [2] [3]. It has been a long dream for human to do our endeavor to make Stratospheric airship fly in the sky from the $70^{\text {th }}$ last century. For the reasons of special atmospheric 
environment and technical difficulties, there is no real stratospheric airship to come true up to now [3] [4] [5], even if a demonstration airship with complete technical requirement.

Anyhow, the principle and key technology of the stratospheric airship have been acknowledged gradually by researchers, and some technical demonstration airships and some platform for stratosphere were tested in the world [6] [7] [8]. For example, the High Altitude Airship project sponsored by US Department of Defense was carried out at 2006 [9] [10], a demonstration airship named CHHAPP was tested at a height of above 74,000 feet $(22.5 \mathrm{~km})$. The aim of this project is to develop a stratospheric platform known as High-Altitude Platforms or Stratospheric Communication Platforms (SCP) for fixed and mobile applications, including military solutions. Another famous project for the stratospheric platform is rockoon platform [11] which has been investigated to offer a platform into the upper atmosphere to launch the rocket instant of launch rocket on the ground. In this way, the rocket can achieve a higher altitude with lower power.

Shanghai Jiao Tong University started the research of the stratospheric airship in 1999 and had completed the project of demonstrating airship "Tianzhou-1" in 2003, design/assemble/test airship "Zhiyuan-1" [12] from 2007-2009 and "Zhiyuan2" from 2014-2016. A single vector propulsion was installed at stern of airship "Tianzhou-1" to verify flying ability and stability with low thrust. Airship "Zhiyuan1" was a stratospheric technical demonstrate airship [13] [14], which shows many technology of aerodynamic performance, fuel cell power, vector propulsion, flight control system and buoyancy control system, etc. Every subsystem unit in airship "Zhiyuan-1" except structural layout is designed according to the concept and technical requirement of stratospheric airship.

This paper first summarized the technical difference between stratospheric airship and traditional airship, discussed the technical difficulties of stratospheric airship, including material, deformation, temperature effect, energy system, etc., and carried out experiments. Finally obtained the relevant parameters of stratospheric airship design, and forecasted the development direction.

\section{Difference between Stratospheric and Traditional Airship}

\subsection{Atmospheric Environment for Stratospheric Airship}

The process of taking off/down for a stratospheric airship starts in troposphere and work in stratosphere [15] [16] [17]. Being the lowest level of earth's atmosphere, troposphere has almost $75 \%$ of air mass and $90 \%$ of hydrosphere, also there are strong convection flow and turbulence flow. The altitude of the top of the troposphere changes with different latitude and season. it is about $17-18 \mathrm{~km}$ average high in the tropics, $10-12 \mathrm{~km}$ in the temperate zone and $8-9 \mathrm{~km}$ in the high latitude area or polar zone. The height of stratosphere region is from the top of troposphere to the height up to $55 \mathrm{~km}$. Some characteristics of stratosphere are as follows [18] [19]:

1) The temperature of stratosphere below height of $30 \mathrm{~km}$ is $-56^{\circ} \mathrm{C}$, almost 
with a constant value. But it increases quickly above the height of $30 \mathrm{~km}$ and will be $-3^{\circ} \mathrm{C}--7^{\circ} \mathrm{C}$ at the top of stratosphere.

2) There is no strong convection flow while the airflow is stable as well.

3) There are almost no hydrosphere and dust, neither cloud and rain.

4) The ozone layer is centralized at about the height of $22 \mathrm{~km}$.

\subsection{Requirement of Stratospheric Airship}

The density of air at height of $20 \mathrm{~km}$ is only $1 / 15$ of that at sea level, and the weight of payload is only about $3 \%-5 \%$ of that of whole stratospheric airship. That means if payload could be 1 ton, the volume of airship would reach up to $400,000 \mathrm{~m}^{3}$, and the length of airship will reach up to $200 \mathrm{~m}$ or more [20] [21].

The stratospheric airship must have the ability of remaining at $20 \mathrm{~km}$ high for a long time, including the ability of both relative geostationary and mobility. In the process of taking off/down, the stratospheric airship needs to possess all the abilities of the traditional airship working in the troposphere.

\subsection{Differences between Stratospheric and Traditional Airship}

The atmospheric environment of stratosphere is more stable than that of troposphere, so there should be sensitive control system including telemetries and actuators installed on to response accurately, quickly to the change of the environment [22]. Because of the sensitiveness of airship weight and low thrust, the energy configuration is very close to the theoretical level [23]. Thus, the stratospheric airship need some sensitive control system to deal with variable atmospheric situation. And in the process of start-up and taking-down, the stratospheric airship works in the troposphere, so that the high-quality control system of working in both stratosphere and troposphere is essential for stratospheric airship. It is known that the popular used energy redundancy index (power carried/power need) is at least 3.0 to make sure there is enough power for traditional airship working in troposphere situation. The control system of traditional airship is just like the way of drone. Some differences technical indicators among tropospheric airship, traditional airship, airship "Tianzhou-1" and airship "Zhiyuan-1" are listed in Table 1.

\section{Main Technology Difficulties}

\subsection{Material}

The material property requirements of the hull for the stratospheric airship are determined according to resist of atmosphere environment and mechanical requirement of the huge volume of the hull [24] [25] [26]. The weather resistance equipment is possessed to resist the high concentration ozone, energetic ion attack from space, the alternation of high and low temperature and so on. The mechanical properties are needed to fit the needs of high stress and large deformation for the low stiffness of huge volume [27] [28]. The areal density is less than $180 \mathrm{~g} / \mathrm{m}^{2}$ and tension strength should be more than $1000 \mathrm{~N} / \mathrm{cm}$ for the 
Table 1. Differences for different airships.

\begin{tabular}{|c|c|c|c|c|}
\hline Item & Stratospheric airship & Traditional airship & Zhiyuan-1 & Tianzhou-1 \\
\hline Temperature & $-60-+120$ & normal & normal & normal \\
\hline Atmosphere pressure & $1 / 15-1 \mathrm{~atm}$ & normal & normal & normal \\
\hline Ozone environment & high concentration & no & no & no \\
\hline Ion environment & yes & no & no & no \\
\hline Ultraviolet environment & strong & weak & weak & weak \\
\hline Flight duration & long time $>24 \mathrm{~h}$ & $<8 \mathrm{~h}$ & $<4 \mathrm{~h}$ & $<4 \mathrm{~h}$ \\
\hline Wind speed & $\begin{array}{l}\text { depend on probability and } \\
\text { statistics of the wind }\end{array}$ & constant & constant & constant \\
\hline Drag coefficient & $<0.03$ or less & $>0.03$ & 0.0283 & 0.04 \\
\hline Thrust-mass ratio & little & large & little & little \\
\hline Structure type & non-rigid (rigid partly) & no-rigid/ rigid & non-rigid & non-rigid \\
\hline $\begin{array}{l}\text { Material and structure of the } \\
\text { hull }\end{array}$ & $\begin{array}{l}\text { high strength/ } \\
\text { large deformation }\end{array}$ & $\begin{array}{l}\text { low strength/small } \\
\text { deformation }\end{array}$ & $\begin{array}{l}\text { low strength/small } \\
\text { deformation }\end{array}$ & $\begin{array}{l}\text { low strength/small } \\
\text { deformation }\end{array}$ \\
\hline Ballonet & subdivision & no/fixed & Fixed & fixed \\
\hline Fin coefficient & about 0.13 & $0.13-0.188$ & 0.13 & 0.15 \\
\hline Difference of pressure/buoyancy & active control & passive control & active control & passive control \\
\hline Buoyancy compensatory & yes & no & no & no \\
\hline Control mode & remote autonomous & remote/manual & autonomous & autonomous \\
\hline Main energy & solar cell + RFC & fuel/battery & fuel cell + Li battery & Li battery \\
\hline Propeller & high/low density & high density & high density & high density \\
\hline Gondola type & external/build-in & external & external & build-in \\
\hline
\end{tabular}

mechanical property of the hull material which is also including strictly demand against resistance, the leakage rate of the helium and so on. The membrane materials of PBO (Polyparaphenylene Benzom Bisoxazole), Vectran (Polyarylate), Uretek can fulfil some requirement of stratosphere airship, but, but no material up to now can reach to all the technical specification which the stratospheric airship need.

\subsection{Deformation}

For the low density of air in the stratosphere, the airship hull need the very huge volume, which maybe is the largest volume structure up to now. So, the characteristics of the flexibility, mobility, and effect of interaction with wind are appeared [29] remarkably subjected to the load of temperature, gravity, buoyancy, differential pressure, wind flow, and so on. The deformations of the hull are related to all kinds of load, and hardly to be calculated using the method and technology recently. The shape and the volume of the hull will be changed irregularly when the airship flying in the sky, which leads to many difficulties on the determining of aerodynamic parameters in the design of flight control system 
and the shape of hull [30] [31] [32]. While, all the aspect of the design of airship and manufacture for so huge hull has no mature solution nowadays.

Table 2 shows an example of the deformation according to the computational results for 60/120/220 $\mathrm{m}$ long airship hull, respectively, considering the interaction between airship structure and wind-flow under wind $30 \mathrm{~m} / \mathrm{s}$. The Various length of the hull leads to very different deformation level evidently, and the deformation for the hull of $220 \mathrm{~m}$ in length can't be ignored as an airship in the flying situation. Figure 1 shows the deformations of $220 \mathrm{~m}$ long of the hull in the attack angles $20^{\circ}$.

\subsection{Thermal Effect}

The thermal environment at the $20 \mathrm{~km}$ high of stratosphere mainly includes the heat emission of the sun and the earth. Besides, the effect of alternating of day and night has to be taken into account [33] [34]. The buoyancy value and the staying status will be affected by any changes of the thermal environment which leads to the changes of the volume and the shape of the hull.

Usually, a certain degree range of the differential pressure is allowable between outside and inside of the airship hull when the airship is in flying status [35]. The volumes of the ballonets are adjusted to balance the volume change of the hull in which is full of helium. The ballonets will be deflated when temperature is rising, so that the airship will ascend because of the loss of the air. On the contrast, the ballonets will be inflated when the temperature of the hull is dropping, the airship will descend because of the increase of air mass. A continuous inflating process will be taken to maintain the shape of the hull caused by the change of atmospheric pressure and the air density as the airship descend or ascend.

Table 2. Relationship between max deformation and envelope scale $(\mathrm{v}=30 \mathrm{~m} / \mathrm{s})$.

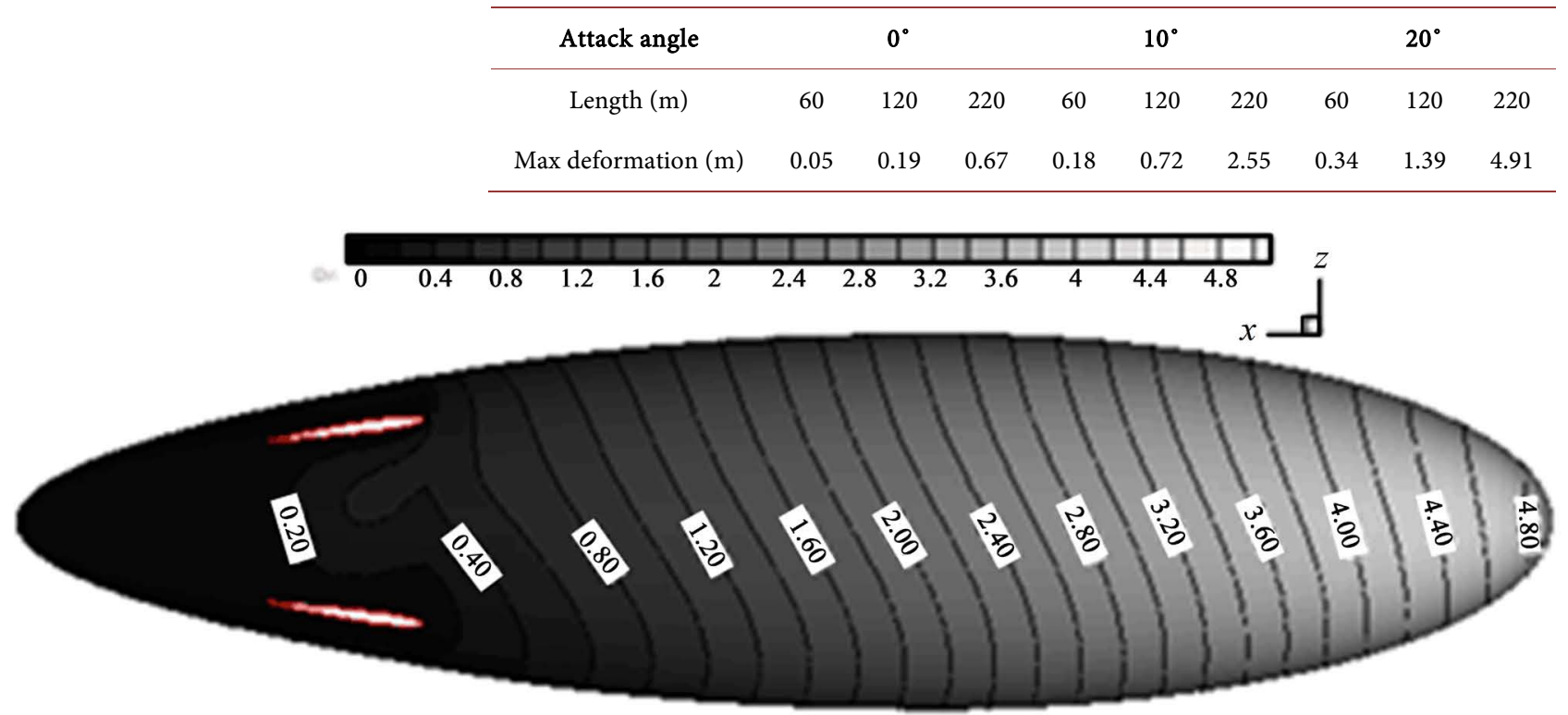

Figure 1. Deformation of the hull under the wind-flow $\left(220 \mathrm{~m}, \mathrm{~V}=30 \mathrm{~m} / \mathrm{s}, \alpha=20^{\circ}\right)$. 
The range of temperature is about $74^{\circ} \mathrm{C}\left(\right.$ from $-55^{\circ} \mathrm{C}$ to $\left.19^{\circ} \mathrm{C}\right)$ in the alternate between night and day for the analysis of numerical calculation. It should be noted that, the different calculation results are affected by the location and season [36]. Nevertheless, some unprecedented technical difficulty has to be solved in sucking so great an amount of air into ballonet during a certain time in a so rarefied atmospheric environment. In addition, it is looking for a new technique to keep maintaining the buoyancy of the airship when the temperature changes.

\subsection{Energy System}

Energy redundancy is designed for the traditional airship to provide powerful thrust to resist changes of atmospheric environment [37] [38]. The stratospheric airship has to utilize the small thrust-weight ratio energy system for the low buoyancy in the stratospheric situation. But, in the procedure of taking off and down, the stratospheric airship is working in the troposphere, so it also should have the powerful ability as that of the traditional airship on the process of in the troposphere. That is mean, both disadvantage of energy system in troposphere and stratosphere has to be considered. Generally, the weight of energy system is occupied as about $30 \%$ of the stratospheric airship payload without redundancy when the energy density reached to $400 \mathrm{Wh} / \mathrm{kg}$ [39]. However as far as nowadays, energy density of the products of Li-ion battery is less than $250 \mathrm{Wh} / \mathrm{kg}$ (in the situation of library) and regenerative fuel cell is only about $250 \mathrm{Wh} / \mathrm{kg}$. That means the technology of energy storage will be the key problem.

\subsection{Other Technology Difficulties}

The weight of payloads and the effect of night and day alternate are not considered in the flight tests of so-called demonstrated stratospheric airships. As the matter of the fact, the scale of real stratospheric airship is much larger than that of those airships, and there is more inconsiderable problem existed such as structure layout, aerodynamics configuration and layout, flight control in the process of taking off or taking down, even if the operation at the ground before the airship takes off.

\section{Introduction of Demonstration Airship}

Researching on the stratospheric airship in China starts from 1999. Some flight tests have been carried out to test the technical feasibility of the stratospheric airship among these test, the airship "Tianzhou-1" which was tested in 2006 and airship "Zhiyuan-1" which was test in 2012 are representative ones.

\subsection{Airship "Tianzhou-1"}

The full image and schematic layout of airship "Tianzhou-1" are shown in Figure 2 and Figure 3, respectively. The ratio of length/diameter of the hull is 3.75 with the design length of hull being, and the volume of hull is about $300 \mathrm{~m}^{3}$. The maximum design wind speed is $10 \mathrm{~m} / \mathrm{s}$, and geostationary accuracy is $\pm 100 \mathrm{~m}$ 


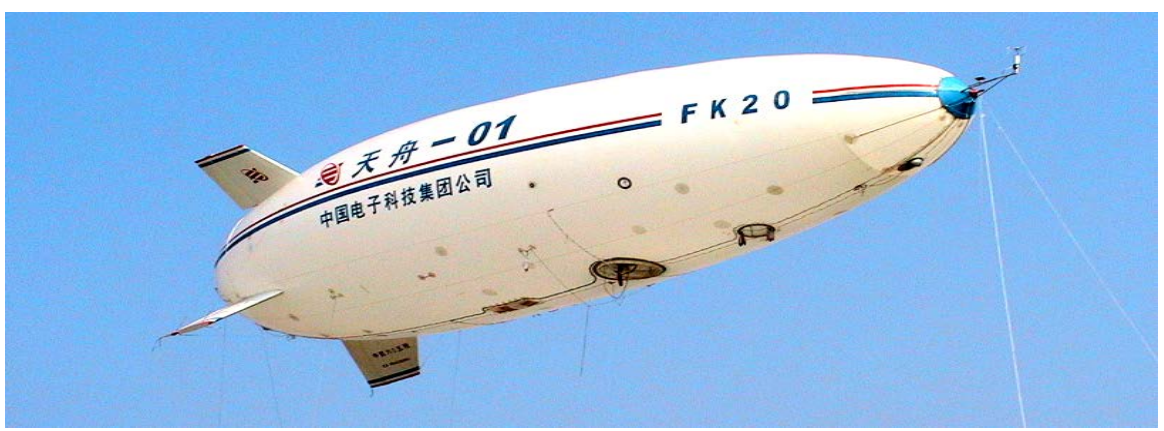

Figure 2. The full picture of "Tianzhou-1".

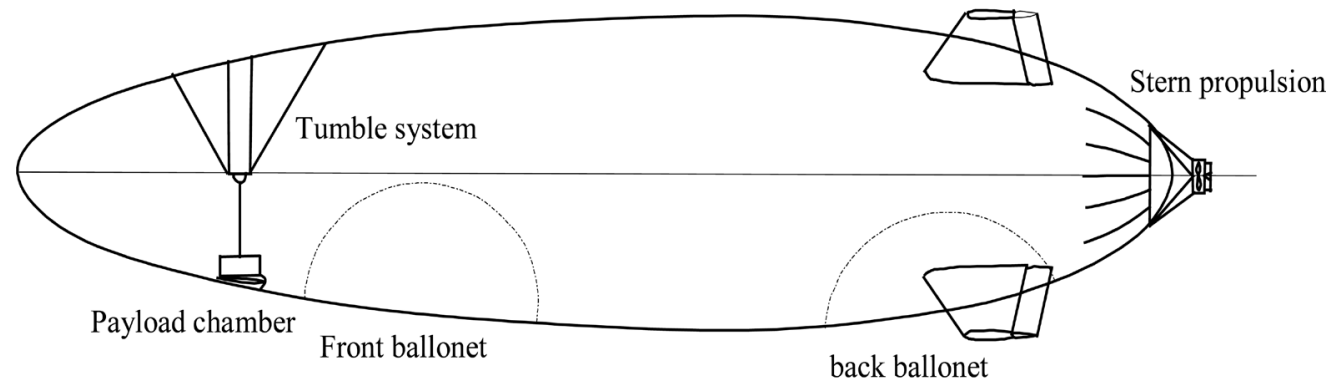

Figure 3. The configuration of "Tianzhou-1".

with autonomous control system. The airship is designed to fly at the altitude $500 \mathrm{~m}$ and the duration staying on the target altitude was designed to $1 \mathrm{~h}$.

Propulsion system was consisted of DC motor $(3.3 \mathrm{~kW} / 300 \mathrm{~V})$, propeller, a duct with 4 flow deflectors to form vector pushing force, 4 fins and some extra auxiliary accessories. Power system was made up of a set of Li-ion battery, which provides $3.3 \mathrm{kw} / 300 \mathrm{~V}$ to propulsion system, $435 \mathrm{~W} / 28 \mathrm{~V}$ power to flight control system and payload. Flight control system was designed into two modes bombinating both remote flight control system and autonomous control system, which can be switch to each other swiftly.

\subsection{Airship "Zhiyuan-1"}

The configuration of airship "Zhiyuan-1" are shown in Figure 4 and Figure 5 [40] [41]. The ratio of length/diameter of the hull is 3.30 , the length $25 \mathrm{~m}$, and the volume of hull is $750 \mathrm{~m}^{3}$. The maximum design wind speed is $8 \mathrm{~m} / \mathrm{s}$ and the barometric height reach to $800 \mathrm{~m}$. Geostationary accuracy is $\pm 100 \mathrm{~m}$ with autonomous control mode. The times of flight duration increase to $4 \mathrm{~h}$.

Three propellers layout is adopted, where two are on the gondola with vector pushing force unit and the other one is on the stern of the hull. The total power of push force unit is $8 \mathrm{~kW}$ which was divided into two parts by different function. The one offers the power to propellers on the gondola and the other offers the power to the propeller on the stern. The power ratio of two parts is 1.0:1.1.

A composited system of $10 \mathrm{~kW}$ fuel cell with hydrogen tank (20 Mpa/140L) and $6.0 \mathrm{~kW}$ Li-ion battery was accepted as a backup power to provide $300 \mathrm{~V}$ electric power to three motors for normal and emergency flight. And a $1.2 \mathrm{~kW}$ 


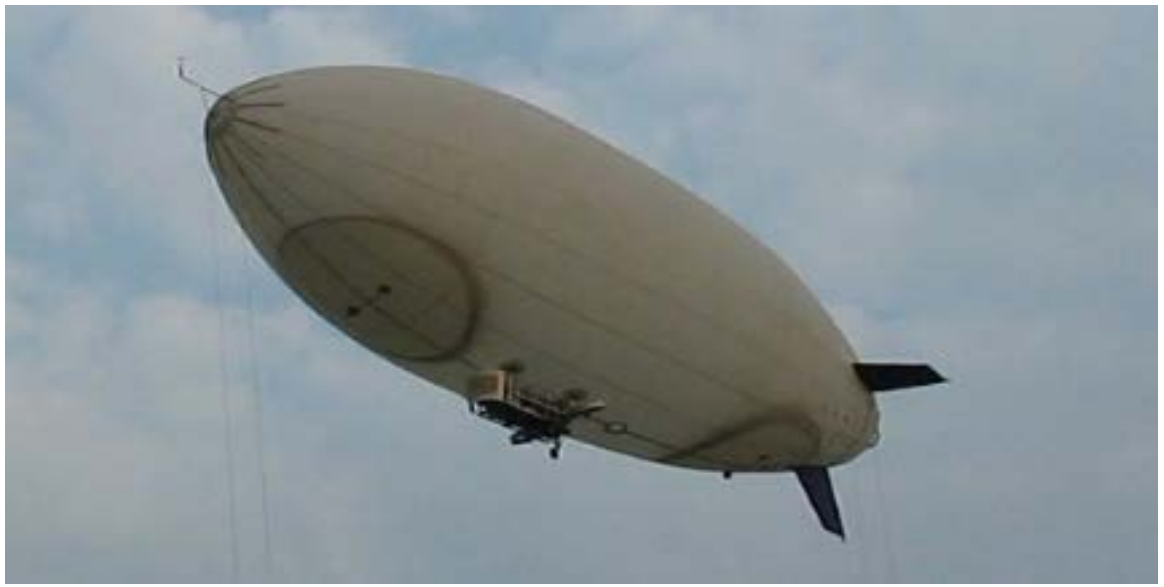

Figure 4. The image of real airship of "Zhiyuan-1".

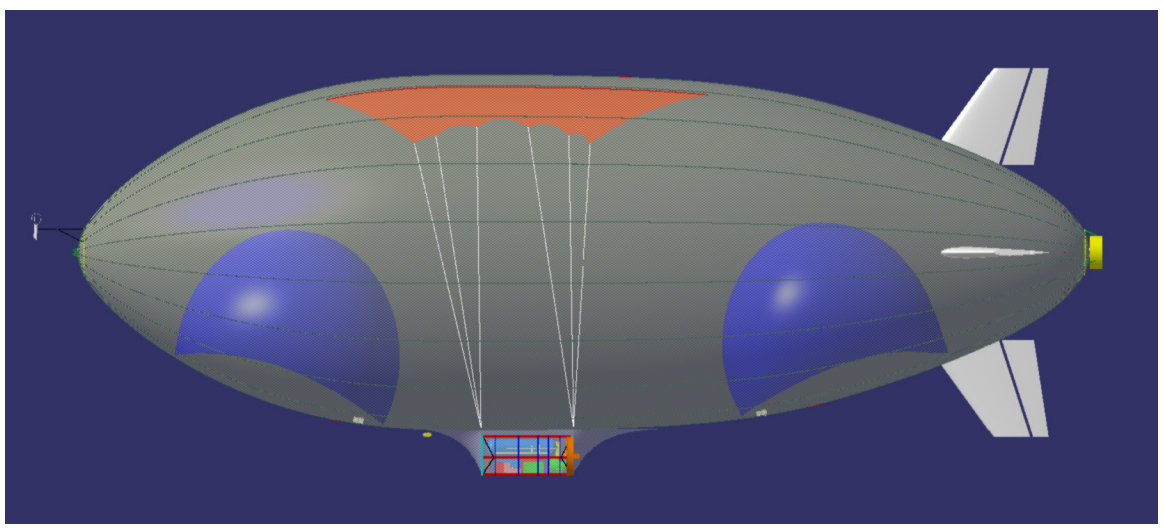

Figure 5. The view of "Zhiyuan-1" configuration.

Li-ion battery provides $1.2 \mathrm{~kW} / 28 \mathrm{~V}$ to flight control system and payload.

Flight control system includes a manual remote controller and autonomous control system, of which can be switch to each other. A mobile ground-based monitor system is set-up in a minibus, including a computer to transmit flight control command or revise flight course and waypoint.

\subsection{Flying Test}

\subsubsection{Geostationary Ability of Airship "TianZhou-1"}

The flight test of the airship "Tianzhou-1" has been conducted from Jan 2013 to Dec 2013. The main goal is to verify flight feasibility, practicability, capability and the stability of the airship with a single vector propeller on stern.

Figure 6 shows a geostationary ability in autonomous flight mode under wind speed $4-6 \mathrm{~m} / \mathrm{s}$ at $300 \mathrm{~m}$ altitude, of which the flight test has been continuous about $55 \mathrm{~min}$. The airship can adjust its flying direction automatically to maintain itself toward against the wind-flow and try to move to the waypoint predetermined.

\subsubsection{Trace of Airship "Zhiyuan-1"}

There are totally 12 sorties in the demonstration test of the airship "Zhiyuan-1". 
It were carried out during Sep 2009 to Dec 2009. In this test, manual control system was used in the process of taking off/down of the airship, remote control and autonomous control mode was switched each other during the situation of troposphere and stratosphere. Max continuous flying time reached to 80 mins., and max resisted wind-flow was $10 \mathrm{~m} / \mathrm{s}$ with thrust power $6.1 \mathrm{~kW}$. Figure 7 shows a trace of flying test under the wind speed $6-8 \mathrm{~m} / \mathrm{s}$ at the altitude $400 \mathrm{~m}$. The test results indicated that the airship "Zhiyuan-1" possess a good maneuverability.

\subsection{Main Design Characteristic}

\subsubsection{Aerodynamic Drag}

The main characteristic of stratospheric airship is to keep a small drag coefficient

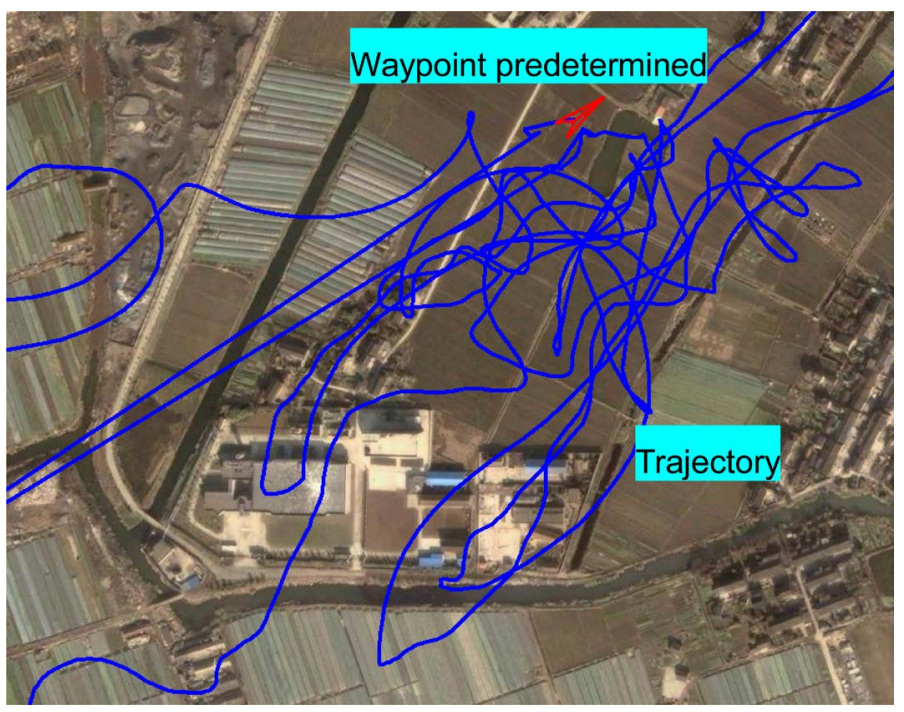

Figure 6. Geostationary ability of airship “Tianzhou-1".

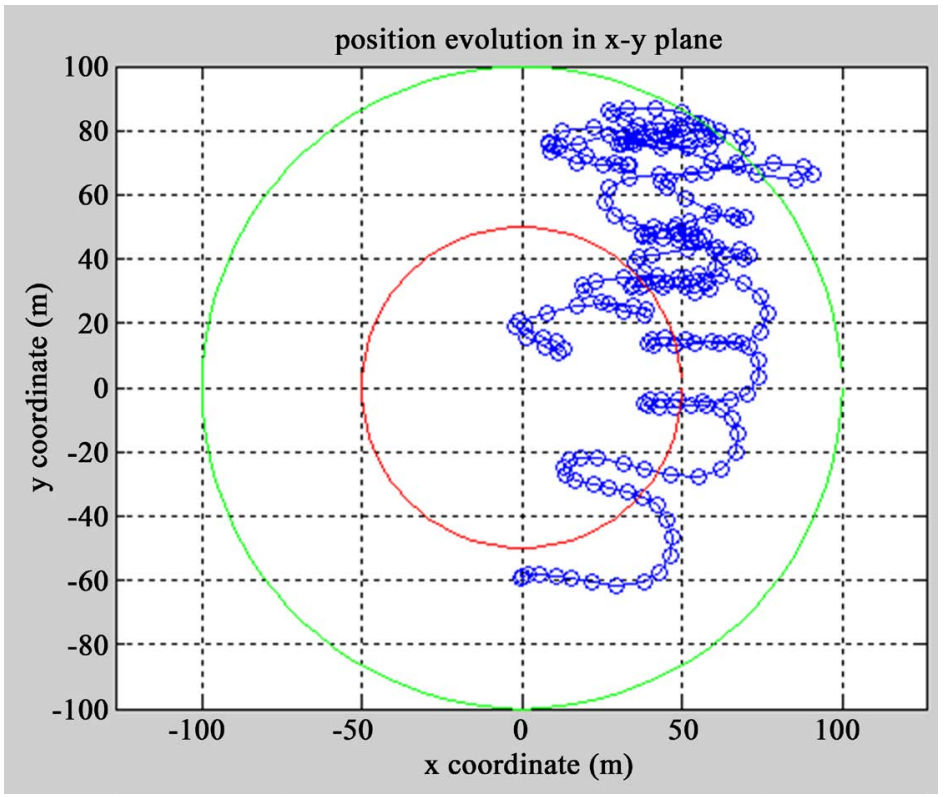

Figure 7. Maneuverability of "Zhiyuan-1". 
to reduce the weight of power system cells. The configuration shape of "Zhiyuan-1" is formed by the rotation of a profile line. And the profile line had a very excellent aerodynamic characteristic which was obtained by Michel transition law. To verify the precise drag coefficient of airship "Zhiyuan-1", the wind tunnel test was carried out with two conditions of having turbulence or not which can be seen as Figure 8. It should be noticed that the wind tunnel test didn't take the deformation of airship hull into accounts, the test model was rigid. The results of wind tunnel test on rigid model of the airship listed in Table 3 shows that the drag coefficient is affected obviously by turbulent flow and gondola. Reducing the turbulent flow and roughness of hull is a good way to decrease the drag coefficient of airship.

\subsubsection{The Ratio of Thrust Power to the Weight}

The ratio of thrust power to the weight of the airship "Tianzhou-1" is 3.3 $\mathrm{kW} / 329 \mathrm{~kg}$, and $6.1 \mathrm{~kW} / 768 \mathrm{~kg}$ for the airship "Zhiyuan-1". The power system of the airship "Zhiyuan-1" is designed according to theoretical idea and there was $30 \%$ redundant in the case of uncertain factors. Table 4 shows the thrust-weight ratios of stratospheric demonstration airships.

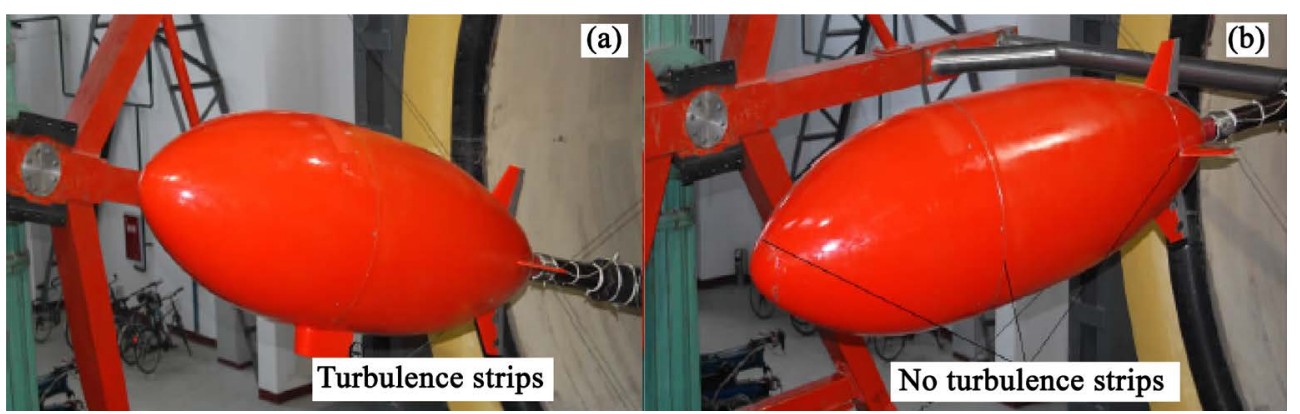

Figure 8. The wind tunnel test of airship model. (a) Having turbulence strips; (b) No turbulence strips

Table 3. Tunnel test result of "Zhiyuan-1" (drag coefficient correction: 0.00356).

\begin{tabular}{ccc}
\hline & Drag coefficient(no transition) & Drag coefficient(transition) \\
\hline Hull & $6.91 \mathrm{e}-03$ & $1.459636 \mathrm{e}-02$ \\
Hull + Fin & $7.85 \mathrm{e}-03$ & $1.646009 \mathrm{e}-02$ \\
Whole airship & $1.98 \mathrm{e}-02$ & $2.829101 \mathrm{e}-02$ \\
\hline
\end{tabular}

Table 4. Thrust-weight ratios of stratospheric demonstration airships.

\begin{tabular}{cccccc}
\hline Airship & $\begin{array}{c}\text { Length of hull } \\
(\mathrm{m})\end{array}$ & $\begin{array}{c}\text { Volume } \\
\left(\mathrm{m}^{3}\right)\end{array}$ & $\begin{array}{c}\text { Flying altitude } \\
(\mathrm{m})\end{array}$ & $\begin{array}{c}\text { Wind speed } \\
(\mathrm{m} / \mathrm{s})\end{array}$ & $\begin{array}{c}\text { Thrust/weight } \\
(\mathrm{kW} / \mathrm{kg})\end{array}$ \\
\hline Tianzhou-1 & 20 & 300 & 500 & 10 & $3.3 / 329$ \\
Zhiyaun-1 & 25 & 793 & 800 & 8 & $6.1 / 768$ \\
Japan & 68.4 & 10660 & 4000 & 15 & $60 / 6400$ \\
Concept (Japan) & 245 & 480,000 & 20,000 & 30 & $195 / 324,000$ \\
\hline
\end{tabular}




\subsubsection{Way of Taking Off/Down}

Using the way of inflating/deflating air of the ballonet to control the buoyancy of the airship, it is available to control the height and vertical velocity of the airship. It was tried successfully in the flight test of "Zhiyuan-1", as a vertical way of taking off/down.

\subsubsection{Aerodynamics Layout}

Single vector propeller and cross tail layout are adopted in the airship "Tianzhou-1", three propellers and cross tail layout in "Zhiyuan-1". When at a turning around during the flying, the former replies on the max output of thrust, and the latter depends on the differential thrust by propellers on the gondola and the flow effect of vertical fin. In a word, the type of three propeller layout has a better flying capability than that of single propeller.

\section{Summary}

Compared to the traditional airship, the design requirements of stratospheric are strictly limited because of complexity of the working conditions. This paper described some characteristics of the stratospheric airship, and the technical differences between the traditional airship and stratospheric airship. Two demonstration airship tests are introduced which are designed to find out the basic ability for stratospheric airship in Shanghai Jiao Tong University of China. According to the result of two demonstration test, the conclusion below can be found,

1) Stratospheric airship has to possess the high-quality specification related to working in stratosphere. And still, it has to have the capacity to work in troposphere.

2) Some foundational research should be carried out for the stratospheric airship, including membrane material, regenerative energy system, structural properties of huge volume inflated membrane in different working conditions, and so on. The dimension affect should be taken seriously as a real stratospheric airship in research.

3) Airship with single vector propeller could satisfy the request of flying stably, which demonstrated by the airship "Tianzhou-1". The concept of the stratospheric airship is demonstrated according the flying test of airship "Zhiyuan-1", of which with a good configuration of hull, small ratio of the thrust power to the weight of the airship, and vertical way of taking off/down.

4) Reducing the turbulent flow and roughness of hull is a good way to decrease the drag coefficient of airship and the type of three propeller layout has a better flying capability than that of single propeller.

\section{Fund}

This work was supported by the National Natural Science Foundation of China (grant numbers 51508238) and by the Jiangsu Postdoctoral Research Plan (grant numbers 1601014B). 


\section{Conflicts of Interest}

The authors declare no conflicts of interest regarding the publication of this paper.

\section{References}

[1] Yang, X. and Liu, D. (2017) Renewable Power System Simulation and Endurance Analysis for Stratospheric Airships. Renewable Energy, 113, 1070-1076. https://doi.org/10.1016/j.renene.2017.06.077

[2] Miao, J., Zhou, J., Nie, Y., et al. (2016) Yaw Controller Design of Stratospheric Airship Based on Phase Plane Method. Chinese Journal of Aeronautics, 29, 738-745. https://doi.org/10.1016/j.cja.2016.04.012

[3] Zhao, S., Liu, D., Zhao, D., et al. (2017) Change Rules of a Stratospheric Airship's Envelope Shape during Ascent Process. Chinese Journal of Aeronautics, 30, 752-758. https://doi.org/10.1016/j.cja.2017.02.017

[4] Tang, Z., Liu, P., Sun, J., et al. (2015) Performance of Contra-Rotating Propellers for Stratospheric Airships. International Journal of Aeronautical and Space Sciences, 16, 485-492. https://doi.org/10.5139/IJASS.2015.16.4.485

[5] Chiba, K., Satori, S., Mitsuhashi, R., et al. (2015) Behavior of Tether for Captive Stratosphere Platform Using Airship. Procedia Engineering, 99, 905-910. https://doi.org/10.1016/j.proeng.2014.12.620

[6] Liu, J.H., Liu, Z.H., Ji, X.M., et al. (2016) Research Status of Stratospheric Airship Envelop Material. Information Record Materials, 17, 1-5.

[7] Li, T., Sun, X.-Y., Zhang, Z.Y. and Lin, G.C. (2017) Numerical Simulation and Formula Fitting of Aerodynamic Drag Force of Stratosphere Airship. Engineering Mechanics, No. 8, 249-256.

[8] Chen, Y., Liu, P., Tang, Z., et al. (2015) Wind Tunnel Tests of Stratospheric Airship Counter Rotating Propellers. Theoretical and Applied Mechanics Letters, 5, 58-61. https://doi.org/10.1016/j.taml.2015.01.001

[9] Jamison, L., Sommer, G.S. and Porche III, I.R. (2006) High-Altitude Airships for the Future Force Army. RAND Corporation, Santa Monica.

[10] Colozza, A. (2013) Initial Feasibility Assessment of a High Altitude Long Endurance Airship. Analex Corporation, Brook Park.

[11] Okninski, A., Raurell, D.S. and Mitre, A.R. (2016) Feasibility of a Low-Cost Sounding Rockoon Platform. Acta Astronautica, 127, 335-344.

https://doi.org/10.1016/j.actaastro.2016.06.010

[12] Wang, X.L., Fu, G.Y., Duan, D.P., et al. (2010) Experimental Investigations on Aerodynamic Characteristics of the ZHIYUAN-1 Airship. Journal of Aircraft, 4, 1463 1468. https://doi.org/10.2514/1.C000243

[13] D'Oliveira, F.A., Melo, F.C.L.D. and Devezas, T.C. (2016) High-Altitude PlatformsPresent Situation and Technology Trends. Journal of Aerospace Technology and Management, 8, 249-262. https://doi.org/10.5028/jatm.v8i3.699

[14] Liu, J., Wang, Q.-B. and Zhao, H.-T. (2013) Optimization Design of the Stratospheric Airship's Power System Based on the Methodology of Orthogonal Experiment. Journal of Zhejiang University Science, 14, 38-46. https://doi.org/10.1631/jzus.A1200138

[15] Du, H., Zhu, W., Wu, Y., et al. (2017) Effect of Angular Losses on the Output Performance of Solar Array on Long-Endurance Stratospheric Airship. Energy Conver- 
sion and Management, 147, 135-144.

https://doi.org/10.1016/j.enconman.2017.05.047

[16] Meng, J., Qu, Z., Zhu, W., et al. (2017) Fatigue Damage Mechanical Model of the Envelope Material for Stratospheric Airships. Applied Composite Materials, 24, 837-848. https://doi.org/10.1007/s10443-016-9556-6

[17] Shen, J.Q., Pan, C., Wang, J.J., et al. (2015) Reynolds-Number Dependency of Boundary-Layer Transition Location on Stratospheric Airship Model. Journal of Aircraft, 52, 1355-1359. https://doi.org/10.2514/1.C032971

[18] Sun, K., Yang, Q., Yang, Y., et al. (2015) Numerical Simulation and Thermal Analysis of Stratospheric Airship. Procedia Engineering, 99, 763-772.

https://doi.org/10.1016/j.proeng.2014.12.600

[19] Lv, M., Li, J., Du, H., et al. (2017) Solar Array Layout Optimization for Stratospheric Airships Using Numerical Method. Energy Conversion and Management, 135, 160 169. https://doi.org/10.1016/j.enconman.2016.12.080

[20] Zhao, D.P. (2007) Structure Performances Analysis of Large Pneumatic Membrane Structure and Experiment on High-Strength Fabrics. Shanghai Jiaotong University Department of Civil Engineering, Shanghai.

[21] Chen, J.W. and Chen, W.-J. (2014) Biaxial Tensile Properties and Elastic Constants Evaluation of Envelope Material for Airship. Journal of Southeast University (English Edition), 30, 467-474.

[22] Yang, X. and Liu, D. (2018) Conceptual Design of Stratospheric Airships Focusing on Energy Balance. Journal of Aerospace Engineering, 31, 1147-1153. https://doi.org/10.1061/(ASCE)AS.1943-5525.0000814

[23] Wang, F., Chen, Y., Xu, W., et al. (2016) Experimental Study on Uniaxial Tensile and Welding Performance of a New Coated Fabric for Airship Envelopes. Journal of Industrial Textiles, 46, 1474-1497. https://doi.org/10.1177/1528083715627164

[24] Hun, R., Tiwari, A. and Sinha, N.K. (2016) Design and Simulation of Autopilot Control System for Stratospheric Airship. IFAC-Papers Online, 49, 712-717. https://doi.org/10.1016/j.ifacol.2016.03.140

[25] Xing, D., Dai, Q. and Liu, C. (2017) Thermal Characteristics and Output Power Performances Analysis of Solar Powered Stratospheric Airships. Applied Thermal Engineering, 123, 770-781. https://doi.org/10.1016/j.applthermaleng.2017.05.168

[26] Lv, M., Yao, Z., Zhang, L., et al. (2017) Effects of Solar Array on the Thermal Performance of Stratospheric Airship. Applied Thermal Engineering, 124, 22-33. https://doi.org/10.1016/j.applthermaleng.2017.06.018

[27] Li, J., Lv, M., Tan, D., et al. (2016) Output Performance Analyses of Solar Array on Stratospheric Airship with Thermal Effect. Applied Thermal Engineering, 104, 743 750. https://doi.org/10.1016/j.applthermaleng.2016.05.122

[28] Li, J., Lv, M., Sun, K., et al. (2016) Thermal Insulation Performance of Lightweight Substrate for Solar Array on Stratospheric Airships. Applied Thermal Engineering, 107, 1158-1165. https://doi.org/10.1016/j.applthermaleng.2016.07.045

[29] Lv, M., Li, J., Zhu, W., et al. (2017) A Theoretical Study of Rotatable Renewable Energy System for Stratospheric Airship. Energy Conversion and Management, 140, 51-61. https://doi.org/10.1016/j.enconman.2017.02.069

[30] Ilieva, G., Páscoa, J., Dumas, A., et al. (2014) MAAT-Promising Innovative Design and Green Propulsive Concept for Future Airship's Transport. Aerospace Science and Technology, 35, 1-14. https://doi.org/10.1016/j.ast.2014.01.014

[31] Ceruti, A., Gambacorta, D. and Marzocca, P. (2018) Unconventional Hybrid Air- 
ships Design Optimization Accounting for Added Masses. Aerospace Science and Technology, 72, 164-173. https://doi.org/10.1016/j.ast.2017.10.042

[32] Carrión, M., Biava, M., Steijl, R., et al. (2015) Analysis of Hybrid Air Vehicles Using Computational Fluid Dynamics. Journal of Aircraft, 53, 1001-1012. https://doi.org/10.2514/6.2016-0059

[33] Yang, Y.N., Zheng, W., Yan, Y. and Shao, H.B. (2015) Flight Mode Analysis for Stratospheric Airships. Journal of National University of Defense Technology, 37, 57-64.

[34] Gao, H.J., Chen, W.J., Fu, G.Y., et al. (2014) Structural Analysis of Flexible Airship on Stratospheric Platform Based on Engineering Elastic Theory. Journal of Shanghai Jiaotong University (Science), 44, 1583-1590.

[35] Gao, H.J., Chen, W.J., Fu, G.Y. and He, Y.L. (2012) Deformation Analysis Method and Performance Evaluation for Flexible Airship of Stratospheric Platform Considering. Chinese Journal of Applied Mechanics, 4, 374-379.

[36] Ilieva, G., Páscoa, J., Dumas, A., et al. (2012) A Critical Review of Propulsion Concepts for Modern Airships. Open Engineering, 2, 189-200.

https://doi.org/10.2478/s13531-011-0070-1

[37] Chen, L., Dong, Q., Zhang, G., et al. (2018) Composite Control System of Hybrid-Driven Mid-Altitude Airship. The Aeronautical Journal, 122, 173-204. https://doi.org/10.1017/aer.2017.125

[38] Yu, D. and Lv, X. (2010) Configurations Analysis for High-Altitude/Long-Endurance Airships. Aircraft Engineering and Aerospace Technology, 82, 48-59. https://doi.org/10.1108/00022661011028119

[39] Du, H., Li, J., Zhu, W., et al. (2018) Thermal Performance Analysis and Comparison of Stratospheric Airships with Rotatable and Fixed Photovoltaic Array. Energy Conversion and Management, 158, 373-386. https://doi.org/10.1016/j.enconman.2017.12.078

[40] Kai, G., Yong, I. and Ke, J. (2016) The Impact of a Large Airship Hangar on the Aerodynamic Forces of Stratospheric Airship. Computer Simulation, 33, 47-53.

[41] Wu, J.T., Ma, Z.Y., Hou, Z.X., et al. (2016) Numerical Research on Forced Convective Heat Transfer of Stratospheric Airships. Journal of National University of Defense Technology, 38, 177-183. 